\title{
Activating and inactivating mutations of the human, rat, equine and eel luteinizing hormone/ chorionic gonadotropin receptors (LH/CGRs)
}

\author{
Kwan-Sik Min ${ }^{1,2,3, *}$, Munkhzaya Byambaragchaa ${ }^{1}$, Seung-Hee Choi ${ }^{2}$, Hyo-Eun Joo ${ }^{3}$, \\ Sang-Gwon Kim ${ }^{3}$, Yean-Ji Kim ${ }^{3}$ and Gyeong-Eun Park ${ }^{3}$ \\ ${ }^{1}$ Institute of Genetic Engineering, Hankyong National University, Ansung 17579, Korea \\ ${ }^{2}$ Department of Animal Biotechnology, Graduate School of Hankyong National University, Ansung 17579, Korea \\ ${ }^{3}$ Department of Animal Life Science, Hankyong National University, Ansung 17579, Korea
}

Received November 19, 2021

Revised December 2, 2021

Accepted December 3, 2021

*Correspondence

Kwan-Sik Min

E-mail: ksmin@hknu.ac.kr

Author's Position and Orcid no. Min KS, Professor,

https://orcid.org/0000-0002-5451-3085 Byambaragchaa M, Research professor,

https://orcid.org/0000-0002-0277-1816 Choi SH, Ms student,

https://orcid.org/0000-0002-9550-6113 Joo HE, Undergraduate student,

https://orcid.org/0000-0002-8387-0428

Kim SG, Undergraduate student,

https://orcid.org/0000-0003-3976-0931

Kim YJ, Undergraduate student,

https://orcid.org/0000-0002-8411-2100

Park GE, Undergraduate student,

https://orcid.org/0000-0003-1740-3036

\begin{abstract}
Mutations in the luteinizing hormone/chorionic gonadotropin receptors (LH/CGRs), representatives of the G protein-coupled receptor family, have been rapidly identified over the last 20 years. This review aims to compare and analyze the data reported the activating and inactivating mutations of the LH/CGRs between human, rat, equine and fish, specifically (Japanese eel Anguilla japonica). Insights obtained through detailed study of these naturally-occurring mutations provide a further update of structure-function relationship of these receptors. Specifically, we present a variety of data on eel LH/CGR. These results provide important information about LH/CGR function in fish and the regulation of mutations of the highly conserved amino acids in glycoprotein hormone receptors.
\end{abstract}

Keywords: activating LH/CG receptor, fish (eel), inactivating LH/CGR, mammalian

\section{INTRODUCTION}

Gonadotropin receptors, such as luteinizing hormone/ chorionic gonadotropin receptor (LH/CGR), belong to a large superfamily of $\mathrm{G}$ protein-coupled receptors (GPCRs) characterized functionally by their interaction with guanine nucleotide-binding proteins and structurally by their seven transmembrane spanning domains, extracellular amino-terminus, and intracellular carboxy-terminus (Min et al., 1998; Byambaragchaa et al., 2021a).
GPCRs exert their effects through $G$ proteins, found at the cytoplasmic face of a cell's plasma membrane. G proteins are composed of three subunits: alpha $(\alpha)$, beta $(\beta)$, and gamma $(\gamma)$. The $\mathrm{G} \alpha$ subunit contains a highly conserved GTPase domain. The G protein $\beta$ - and $\gamma^{\text {-subunits }}$ form a functional unit that can only be dissociated under denaturing conditions. Different combinations of these three subunits are important in governing the diverse signaling pathways regulated by GPCRs (Oldham and Hamm, 2008). These $G \alpha$ subunits are divided into four classes: 
Gas, Gai, Gaq, and Ga12 (Syrovatkina et al., 2016). Gas and Gai transmit signals by stimulating or inhibiting adenylate cyclase, respectively, thereby controlling cyclic AMP levels.

The receptors of glycoprotein hormones use two specific pathways. The cyclic AMP (cAMP)-dependent protein kinase A (PKA) pathway which produces cAMP via adenylate cyclase. The protein kinase $\mathrm{C}$ pathway works in concert with the $\mathrm{Ca}^{2+}$-dependent activation of phospholipase C (Byambaragchaa et al., 2021a). These pathways then initiate intracellular phosphorylation cascades to control a diverse range of processes in growth and metabolism (Ascoli, 2007; Sente et al., 2018).

Similar to other GPCRs, the agonist-induced activation and subsequent phosphorylation of LH/CGRs are important steps for agonist-induced internalization (Levoye et al., 2015; Byambaragchaa et al., 2021a). These receptors are distributed throughout the plasma membrane, but upon agonist activation, they cluster in clathrin-coated pits. The clustered agonist-receptor complex is internalized and moves to the endosomal compartment without ligand dissociation (Lazari et al., 1998; Slosky et al., 2020; Jones et al., 2021). Most of the internalized receptoragonist complexes are transported to the lysosome where the agonist and receptor are degraded (Kishi et al., 2001). In some cases, the complex accumulates in endosomes and the receptor is later recycled back to the cell surface where it is again available to bind to agonist (Krishnamurthy et al., 2003; Foster et al., 2019; Zhou et al., 2021). Whether the number of available cell surface receptors are reduced or maintained is determined by these internalized gonadotropin receptor recycling or degradation processes (Galet et al., 2003, 2004; Hirakawa and Ascoli, 2003; Foster et al., 2017; Byambaragchaa et al., 2020, 2021a). Receptor recycling promotes the maintenance of cell surface receptors and preserves responsiveness to agonists such as hormones (Bhaskaran and Ascoli, 2005; Byambaragchaa et al., 2021a,b).

The first naturally-occurring GPCR mutation was reported due to study of the human disease it causes (Dryja et al., 1990). Excellent reviews on GPCRs in general have been published (Themmen and Huhtaniemi, 2000; Schöneberg et al., 2004; Spiegel and Weinstein, 2004; Themmen, 2005; Tao, 2006, 2008; Althumairy et al., 2020) together with many reviews specifically concerning mutations in individual GPCRs. In this review, we focus on the biological activity of cAMP signal transduction following agonist treatment, cell-surface loss of receptors, and summarizing the impact of receptor mutations in the fish (Japanese eel Anguilla japonica) LH/CGR on these processes. These comparative data reveal how the activating/ inactivating mutants both of mammalian and fish affect signal transduction in the LH/CGR-LH or eCG complex in the highly conserved region of LH/CGR. New studies are just beginning to reveal an important signal transduction for GPCR pathway.

\section{Activating mutations}

LH/CG receptor mutations can activate precocious puberty in boys, whereas, inactivating mutations can cause anovulation in women and block sexual maturation in men (Themmen and Huhtaniemi, 2000). Recently, we reported the structure-function of equine LH/CGR (eLH/ CGR) in cells expressing the eLH/CGR activating gene (Byambaragchaa et al., 2021a), as shown in Fig. 1. Four constitutively activating mutants (M398T, L457R, D564G, and D578Y), spontaneous mutations in the human LH/ CGR, were analyzed for cAMP response and cell-surface receptor loss. The eLH/CGR-L457R, -D564G, and -D578Y mutants exhibited 16.9-, 16.4-, and 11.2-fold increases in basal cAMP response, respectively. The eLH/CGR-M398T mutant showed a slight increase (1.4-fold) without agonist treatment. The activating mutants showed rapid rates of cell surface loss of the receptor.

In humans, the LH/CGR (hLH/CGR), hLH/CGR-D578G mutant (equivalent to D578G or D578Y in eLH/CGR), which is inherited in an autosomal dominant malelimited pattern, produced a 4.5 -fold increase in basal cAMP responsiveness in COS-7 cells (Shenker et al., 1993; Kosugi et al., 1996). This demonstrated that it was constitutively active and represented approximately $42 \%$ of the maximal stimulation of the wild-type receptor. The other mutant, D564G in the third intracellular loop, also had elevated basal cAMP production (Laue et al., 1995; Kosugi et al., 1998). The M398T mutant, located in the second transmembrane region, exhibited the same constitutively high basal cAMP levels (Yano et al., 1996), showing that the mutant's cAMP response in the absence of hormone was elevated up to 25 -fold compared to the response of the wild-type receptor (Kraaij et al., 1995). Specifically, the basal cAMP response of the hLH/CGR-L457R mutant was dramatically increased, whereas the maximal cAMP 


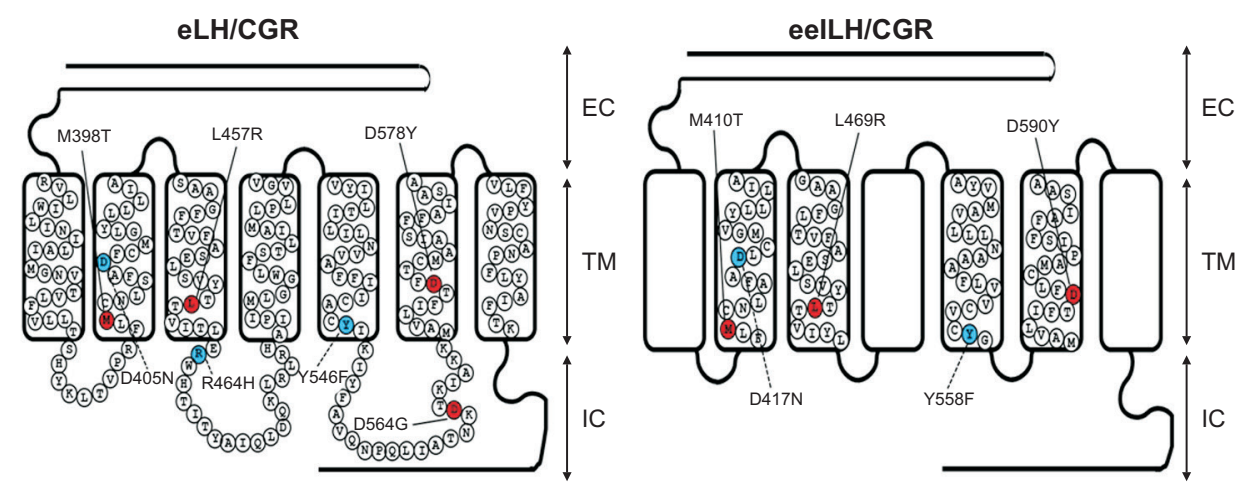

Fig. 1. Schematic representation of the structures of equine and eel LH/CGR (eLH/CGR and eelLH/CGR, respectively). The locations of the constitutive activating mutations (M398T, L457R, D564G, and D578Y) and the inactivating mutations (D405N, R464H, and Y546F) are indicated (left). In the eelLH/CGR, three constitutively activating mutations (M410T, L469R, and D590Y) and two inactivating mutations (D417N and Y558F) are indicated. Amino acid sequences at the mutated sites in the transmembrane domain and intracellular loop are shown in the eLH/CGR. In eelLH/CGR, the transmembrane domain II, III, V, and VI are shown. EC, extracellular domain; TM, transmembrane domain; IC, intracellular domain; LH/CGR, luteinizing hormone/chorionic gonadotropin receptor.

response corresponded to only $40-50 \%$ of the maximal wild-type receptor response (Zhang et al., 2005, 2007; Galet and Ascoli, 2006; Latronico and Segaloff, 2007). Mutations in the transmembrane helix 6 and the third intracellular loop at position 578 are most commonly mutated to glycine (D578G) (Shenker et al., 1993; Laue et al., 1995).

In rats, the LH/CGR-D556G mutant (rLH/CGR-D556G: equivalent to D578Y or D578G in eLH/CGR) is constitutively activating like the D578G mutant eLH/CGR (Bradbury et al., 1997). Therefore, the mutant protein is not processed in the trans-Golgi and remains in its $73 \mathrm{kDa}$ form, remaining predominantly in the endoplasmic reticulum. rLH/CGR-L435R (equivalent to L457R in eLH/ CGR) exhibited a 25-fold increase in basal cAMP and enhanced the internalization of agonist-occupied receptors 17-fold (Min et al., 1998). The phenotype of female knock-in mice in the LH/CGR-D582G has been reported to be distinctly different from women with activating $\mathrm{mu}^{-}$ tations, indicating that the female mice are normal $\left(\mathrm{Na}^{-}\right.$ rayan, 2015). Knock-in mice undergo precocious puberty and are infertile with significant ovarian diseases, such as hemorrhagic cysts, cell hyperplasia, and granulosa cell tumors (Hai et al., 2015).

In eel, we first reported that the activating mutants (eelLH/CGR-M410T, -L469R, and -D590Y) exhibited a 4.0-, 19.1-, and 7.8-fold increase in basal cAMP response without agonist treatment (Byambaragchaa et al., 2021c), indicating that these mutants were found to rapidly cause cell-surface loss of receptors. The loss rates of cell surface agonist-receptor complexes were observed to be very fast (2.6-6.2 $\mathrm{min}$ ) in both the wild-type eel LHR and the activating mutants (in press). We also suggested that the activating mutants in the eel follicle-stimulating hormone receptor (eelFSHR) were consistent, demonstrating that, compared to the wild-type, the basal cAMP response increased considerably and the loss of cell-surface receptor decreased quickly (Byambaragchaa et al., 2020).

\section{Inactivating mutations}

In the testis, LH/CGR is expressed in the Leydig cells, whereas the ovary expresses it in the theca/granulosa cells (Tao, 2006). Thus, loss of function mutations in LH/CGR lead to Leydig cell hypoplasia in males. To date, many studies have reported the effects of eLH/CGR-D405N, eLH/CGR-R464H, eLH/CGR-Y546F (Byambaragchaa et al., 2021a). In the hLH/CGR, many mutations have been reported that hLH/CGR-V144F (Richter-Unruh et al., 2005), hLH/CGR-F194V (Gromoll et al., 2002), hLH/CGRN291S (Laue et al., 1995), hLH/CGR-W491X (RichterUnruh et al., 2002) and hLH/CGR-L502P in TM4 (Leung et al., 2004), and hLH/CGR-A593P and hLH/CGR-S616Y (Tao et al., 2004) have impaired trafficking to the plasma membrane. In rats, the inactivating mutants rLH/CGRD383N (equivalent to D405N in eLH/CGR), rLH/CGRR442H (R464H in eLH/CGR), and rLH/CGR-Y524F (Y546F in eLH/CGR) completely impaired signal transduction, cell surface loss of receptors, and internalization $\mathrm{Ji}$ and $\mathrm{Ji}$, 1991; Dhanwada et al., 1996; Min et al., 1998).

We also reported that the inactivating mutants, eelLH/ 


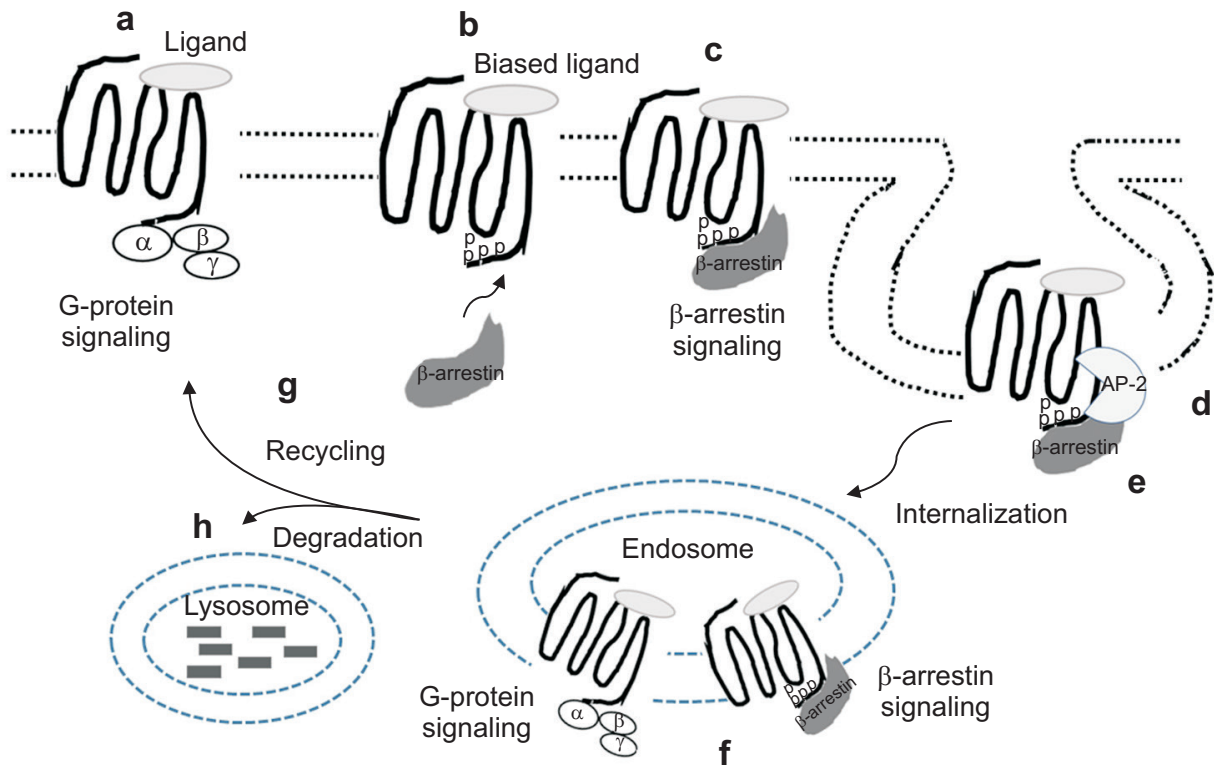

Fig. 2. G-protein signaling and $\beta$-arrestin-regulated internalization of GPCR. Ligands bind to receptor (a) and the phosphorylated receptors at the tail region combine with $\beta$-arrestin in place of $\mathrm{G}$ proteins (b). This is referred as $\beta$-arrestin recruitment (c). Next, $\beta$-arrestin recruit AP2 (adaptor complex) (d). After clathrin-coated vesicle formed (e), receptors with $\beta$-arrestin were internalized into the endosome (f). And then receptors are sorted to recycle back to the plasma membrane (g) and receptor in part degraded in the lysosome (h).
CGR-D417N (equivalent to D405N in eLH/CGR) and eelLH/CGR-Y558F (equivalent to Y546F in eLH/CGR), were impaired in cells expressing both mutant receptors compared to those expressing the wild-type receptor (Byambaragchaa et al., 2021c). However, these mutants did not affect the basal cAMP response, but showed a slightly increased response under high concentrations of agonist. The loss of cell surface receptors in the cells expressing inactivating mutants D417N and Y558F was not observed, despite the treatment with a high concentration of agonist (1000-1500 ng/mL).

\section{SUMMARY AND PERSPECTIVE}

In conclusion, signal transduction of LH/CGRs occurs by PKA-mediated activation, demonstrating that activation mutations are stimulated by constitutively active LH/ CGR mutants. This indicates that inactivating mutations in both mammalian and eel LH/CGRs are completely impaired in the PKA-mediated signaling pathway. However, the key pathway involved in PKA signaling should be examined in detail. The ERK1/2 cascade is a prominent mitogenic pathway activated by agonist-engaged wild-type LH/CGR. Thus, we propose that the LH/CGR-activated ERK1/2 cascade is necessary for the functional analysis of highly constitutively activating LH/CGRs. Primary cells expressing these mutants and animal models with knockin of these genes will provide useful information about these important signaling pathways ( $\beta$-arrestin signaling, internalization, recycling, and downregulation, as shown in Fig. 2) by using new techniques based on the principle of time-resolved fluorescence resonance energy transfer or bioluminescence resonance energy transfer.

Author Contributions: Conceptualization, M.B. and S.H.C.; data curation, H.E.J., S.G.K.; formal analysis, Y.J.K., G.E.P.; Writing, K.S.M.

Funding: None.

Ethical Approval: Not applicable.

Consent to Participate: Not applicable.

Consent to Publish: Not applicable.

Availability of Data and Materials: Not applicable.

Acknowledgements: None.

Conflicts of Interest: No potential conflict of interest relevant to this article was reported.

\section{REFERENCES}

Althumairy D, Zhang X, Baez N, Barisas G, Roess DA, Bousfield GR, Crans DC. 2020. Glycoprotein G-protein coupled receptors in disease: luteinizing hormone receptors and follicle 
stimulating hormone receptors. Diseases 8:35.

Ascoli M. 2007. Potential Leydig cell mitogenic signals generated by the wild-type and constitutively active mutants of the lutropin/choriogonadotropin receptor (LHR). Mol. Cell. Endocrinol. 260-262:244-248.

Bhaskaran RS and Ascoli M. 2005. The post-endocytotic fate of the gonadotropin receptors is an important determinant of the desensitization of gonadotropin responses. J. Mol. Endocrinol. 34:447-457.

Bradbury FA, Kawate N, Foster CM, Menon KM. 1997. Posttranslational processing in the Golgi plays a critical role in the trafficking of the luteinizing hormone/human chorionic gonadotropin receptor to the cell surface. J. Biol. Chem. 272:5921-5926.

Byambaragchaa M, Ahn TY, Choi SH, Kang MH, Min KS. 2021b. Functional characterization of naturally-occurring constitutively activating/inactivating mutations in equine folliclestimulating hormone receptor (eFSHR). Anim. Biosci. (inpress).

Byambaragchaa M, Choi SH, Kim DW, Min KS. 2021c. Constitutive activating eel luteinizing hormone receptors induce constitutively signal transduction and inactivating mutants impair biological activity. Dev. Reprod. 25:133-143.

Byambaragchaa M, Kim JS, Park HK, Kim DJ, Hong SM, Kang MH, Min KS. 2020. Constitutive activation and inactivation of mutations inducing cell surface loss of receptor and impairing of signal transduction of agonist-stimulated eel follicle-stimulating hormone receptor. Int. J. Mol. Sci. 21:7075.

Byambaragchaa M, Seong HK, Choi SH, Kim DJ, Kang MH, Min KS. 2021a. Constitutively activating mutants of equine LH/ CGR constitutively induce signal transduction and inactivating mutations impair biological activity and cell-surface receptor loss in vitro. Int. J. Mol. Sci. 22:10723.

Dhanwada KR, Vijapurkar U, Ascoli M. 1996. Two mutations of the lutropin/choriogonadotropin receptor that impair signal transduction also interfere with receptor-mediated endocytosis. Mol. Endocrinol. 10:544-554.

Dryja TP, McGee TL, Reichel E, Hahn LB, Cowley GS, Yandell DW, Sandberg MA, Berson EL. 1990. A point mutation of the rhodopsin gene in one form of retinitis pigmentosa. Nature 343:364-366.

Foster SR and Bräuner-Osborne H. 2018. Investigating internalization and intracellular trafficking of GPCRs: new techniques and real-time experimental approaches. Handb. Exp. Pharmacol. 245:41-61.

Foster SR, Hauser AS, Vedel L, Strachan RT, Huang XP, Gavin AC, Shah SD, Nayak AP, Haugaard-Kedström LM, Penn RB, Roth BL, Bräuner-Osborne H, Gloriam DE. 2019. Discovery of human signaling systems: pairing peptides to $\mathrm{G}$ proteincoupled receptors. Cell 179:895-908.e21.

Galet C and Ascoli M. 2006. A constitutively active mutant of the human lutropin receptor (hLHR-L457R) escapes lysosomal targeting and degradation. Mol. Endocrinol. 20:29312945.

Galet C, Hirakawa T, Ascoli M. 2004. The postendocytotic traf- ficking of the human lutropin receptor is mediated by a transferable motif consisting of the C-terminal cysteine and an upstream leucine. Mol. Endocrinol. 18:434-446.

Galet C, Min L, Narayanan R, Kishi M, Weigel NL, Ascoli M. 2003. Identification of a transferable two-amino-acid motif (GT) present in the C-terminal tail of the human lutropin receptor that redirects internalized G protein-coupled receptors from a degradation to a recycling pathway. Mol. Endocrinol. 17:411-422.

Gromoll J, Schulz A, Borta H, Gudermann T, Teerds KJ, Greschniok A, Nieschlag E, Seif FJ. 2002. Homozygous mutation within the conserved Ala-Phe-Asn-Glu-Thr motif of exon 7 of the LH receptor causes male pseudohermaphroditism. Eur. J. Endocrinol. 147:597-608.

Hai L, McGee SR, Rabideau AC, Paquet M, Narayan P. 2015. Infertility in female mice with a gain-of-function mutation in the luteinizing hormone receptor is due to irregular estrous cyclicity, anovulation, hormonal alterations, and polycystic ovaries. Biol. Reprod. 93:16.

Hirakawa T and Ascoli M. 2003. The lutropin/choriogonadotropin receptor-induced phosphorylation of the extracellular signal-regulated kinases in Leydig cells is mediated by a protein kinase A-dependent activation of Ras. Mol. Endocrinol. 17:2189-2200.

Ji I and Ji TH. 1991. Asp383 in the second transmembrane domain of the lutropin receptor is important for high affinity hormone binding and cAMP production. J. Biol. Chem. 266:14953-14957.

Jones B, McGlone ER, Fang Z, Pickford P, Corrêa IR Jr, Oishi A, Jockers R, Inoue A, Kumar S, Görlitz F, Dunsby C, French PMW, Rutter GA, Tan T, Tomas A, Bloom SR. 2021. Genetic and biased agonist-mediated reductions in $\beta$-arrestin recruitment prolong cAMP signaling at glucagon family receptors. J. Biol. Chem. 296:100133.

Kishi M, Liu X, Hirakawa T, Reczek D, Bretscher A, Ascoli M. 2001. Identification of two distinct structural motifs that, when added to the $\mathrm{C}$-terminal tail of the rat $\mathrm{LH}$ receptor, redirect the internalized hormone-receptor complex from a degradation to a recycling pathway. Mol. Endocrinol. 15:1624-1635.

Kosugi S, Mori T, Shenker A. 1996. The role of Asp578 in maintaining the inactive conformation of the human lutropin/ choriogonadotropin receptor. J. Biol. Chem. 271:3181331817.

Kosugi S, Mori T, Shenker A. 1998 . An anionic residue at position 564 is important for maintaining the inactive conformation of the human lutropin/choriogonadotropin receptor. Mol. Pharmacol. 53:894-901.

Kraaij R, Post M, Kremer H, Milgrom E, Epping W, Brunner HG, Grootegoed JA, Themmen AP. 1995. A missense mutation in the second transmembrane segment of the luteinizing hormone receptor causes familial male-limited precocious puberty. J. Clin. Endocrinol. Metab. 80:3168-3172.

Krishnamurthy H, Kishi H, Shi M, Galet C, Bhaskaran RS, Hirakawa T, Ascoli M. 2003. Postendocytotic trafficking of the 
follicle-stimulating hormone (FSH)-FSH receptor complex. Mol. Endocrinol. 17:2162-2176.

Latronico AC and Segaloff DL. 2007. Insights learned from L457(3.43)R, an activating mutant of the human lutropin receptor. Mol. Cell. Endocrinol. 260-262:287-293.

Laue L, Chan WY, Hsueh AJ, Kudo M, Hsu SY, Wu SM, Blomberg L, Cutler GB Jr. 1995. Genetic heterogeneity of constitutively activating mutations of the human luteinizing hormone receptor in familial male-limited precocious puberty. Proc. Natl. Acad. Sci. U. S. A. 92:1906-1910.

Lazari MF, Bertrand JE, Nakamura K, Liu X, Krupnick JG, Benovic JL, Ascoli M. 1998. Mutation of individual serine residues in the $\mathrm{C}$-terminal tail of the lutropin/choriogonadotropin receptor reveal distinct structural requirements for agonist-induced uncoupling and agonist-induced internalization. J. Biol. Chem. 273:18316-18324.

Leung MY, Al-Muslim O, Wu SM, Aziz A, Inam S, Awadh M, Rennert OM, Chan WY. 2004. A novel missense homozygous inactivating mutation in the fourth transmembrane helix of the luteinizing hormone receptor in Leydig cell hypoplasia. Am. J. Med. Genet. A 130A:146-153.

Levoye A, Zwier JM, Jaracz-Ros A, Klipfel L, Cottet M, Maurel D, Bdioui S, Balabanian K, Prézeau L, Trinquet E, Durroux T, Bachelerie F. 2015. A broad G protein-coupled receptor internalization assay that combines SNAP-tag labeling, diffusion-enhanced resonance energy transfer, and a highly emissive terbium cryptate. Front. Endocrinol. (Lausanne) 6:167.

Min KS, Liu X, Fabritz J, Jaquette J, Abell AN, Ascoli M. 1998. Mutations that induce constitutive activation and mutations that impair signal transduction modulate the basal and/or agonist-stimulated internalization of the lutropin/choriogonadotropin receptor. J. Biol. Chem. 273:34911-34919.

Narayan P. 2015. Genetic models for the study of luteinizing hormone receptor function. Front. Endocrinol. (Lausanne) 6:152.

Oldham WM and Hamm HE. 2008. Heterotrimeric G protein activation by G-protein-coupled receptors. Nat. Rev. Mol. Cell Biol. 9:60-71.

Richter-Unruh A, Korsch E, Hiort O, Holterhus PM, Themmen AP, Wudy SA. 2005. Novel insertion frameshift mutation of the $\mathrm{LH}$ receptor gene: problematic clinical distinction of Leydig cell hypoplasia from enzyme defects primarily affecting testosterone biosynthesis. Eur. J. Endocrinol. 152:255259.

Richter-Unruh A, Martens JW, Verhoef-Post M, Wessels HT, Kors WA, Sinnecker GH, Boehmer A, Drop SL, Toledo SP, Brunner HG, Themmen AP. 2002. Leydig cell hypoplasia: cases with new mutations, new polymorphisms and cases without mutations in the luteinizing hormone receptor gene. Clin. Endocrinol. (Oxf.) 56:103-112.

Schöneberg T, Schulz A, Biebermann H, Hermsdorf T, Römpler H, Sangkuhl K. 2004. Mutant G-protein-coupled receptors as a cause of human diseases. Pharmacol. Ther. 104:173-
206.

Sente A, Peer R, Srivastava A, Baidya M, Lesk AM, Balaji S, Shukla AK, Babu MM, Flock T. 2018. Molecular mechanism of modulating arrestin conformation by GPCR phosphorylation. Nat. Struct. Mol. Biol. 25:538-545.

Shenker A, Laue L, Kosugi S, Merendino JJ Jr, Minegishi T, Cutler GB Jr. 1993. A constitutively activating mutation of the luteinizing hormone receptor in familial male precocious puberty. Nature 365:652-654.

Slosky LM, Bai Y, Toth K, Ray C, Rochelle LK, Badea A, Chandrasekhar R, Pogorelov VM, Abraham DM, Atluri N, Peddibhotla S, Hedrick MP, Hershberger P, Maloney P, Yuan H, Li Z, Wetsel WC, Pinkerton AB, Barak LS, Caron MG. 2020. $\beta$ -arrestin-biased allosteric modulator of NTSR1 selectively attenuates addictive behaviors. Cell 181:1364-1379.e14.

Spiegel AM and Weinstein LS. 2004. Inherited diseases involving $\mathrm{G}$ proteins and $\mathrm{G}$ protein-coupled receptors. Annu. Rev. Med. 55:27-39.

Syrovatkina V, Alegre KO, Dey R, Huang XY. 2016. Regulation, signaling, and physiological functions of G-proteins. J. Mol. Biol. 428:3850-3868.

Tao YX. 2006. Inactivating mutations of G protein-coupled receptors and diseases: structure-function insights and therapeutic implications. Pharmacol. Ther. 111:949-973.

Tao YX. 2008. Constitutive activation of G protein-coupled receptors and diseases: insights into mechanisms of activation and therapeutics. Pharmacol. Ther. 120:129-148.

Tao YX, Johnson NB, Segaloff DL. 2004. Constitutive and agonist-dependent self-association of the cell surface human lutropin receptor. J. Biol. Chem. 279:5904-5914.

Themmen AP. 2005. An update of the pathophysiology of human gonadotrophin subunit and receptor gene mutations and polymorphisms. Reproduction 130:263-274.

Themmen APN and Huhtaniemi IT. 2000. Mutations of gonadotropins and gonadotropin receptors: elucidating the physiology and pathophysiology of pituitary-gonadal function. Endocr. Rev. 21:551-583.

Yano K, Kohn LD, Saji M, Kataoka N, Okuno A, Cutler GB Jr. 1996. A case of male-limited precocious puberty caused by a point mutation in the second transmembrane domain of the luteinizing hormone choriogonadotropin receptor gene. Biochem. Biophys. Res. Commun. 220:1036-1042.

Zhang M, Mizrachi D, Fanelli F, Segaloff DL. 2005. The formation of a salt bridge between helices 3 and 6 is responsible for the constitutive activity and lack of hormone responsiveness of the naturally occurring L457R mutation of the human lutropin receptor. J. Biol. Chem. 280:26169-26176.

Zhang M, Tao YX, Ryan GL, Feng X, Fanelli F, Segaloff DL. 2007. Intrinsic differences in the response of the human lutropin receptor versus the human follitropin receptor to activating mutations. J. Biol. Chem. 282:25527-25539.

Zhou Y, Meng J, Xu C, Liu J. 2021. Multiple GPCR functional assays based on resonance energy transfer sensors. Front. Cell Dev. Biol. 9:611443. 